\title{
Analysis of the Application of Social E-commerce Marketing
}

\author{
Libo Wen,Yeqian Ni,Bin Huang \\ School of Media Studies\&Humanities , Zhejiang University City College , Hangzhou,10015, China \\ E-mail:583286027@qq.com
}

\begin{abstract}
During the e-commerce boom period, many traditional companies have joined the e-commerce market, and enterprise users of e-commerce sites have reached saturation. Enterprises that only rely on the site's navigation or search systems have been unable to meet the needs of users. Social ecommerce which combines social media with traditional ecommerce has become a mainstream trend. In this paper, the development status of social e-commerce will be discussed, in order to provide the development strategy to solve social ecommerce marketing issues.
\end{abstract}

Keywords-e-commerce; social e-commerce; SNS; micro blogging marketing

*Libo Wen is the first author; Yeqian Ni is the correspondence author;Bin Huang is the instructor.

\section{INTRODUCTION}

With the rapid development of the economy and the rise of e-commerce, enterprise users of the e-commerce market have reached saturation. Entrepreneurs shouldn't expect to gain more profits just relying on website search system. The rapid development of social media has brought new opportunities for the development of e-commerce enterprises. The combination of social media and ecommerce has become a new model for the current development of e-commerce businesses.

\section{CURRENT SituATION OF CHINA’s E-COMMERCE}

In recent years, e-commerce market in China has developed rapidly. The monitoring data from China Electronic Commerce Research Center shows that at the end of June 2012, the number of China e-commerce service enterprises has reached 38,780 , which is an increase of $8 \%$ than before. However, China Electronic Commerce Research Center believes that compared with before, the year-on-year growth rate of domestic e-commerce service enterprises has tended to a downward trend. In this regard, this is because of the influence of international and domestic economic downturn. On the other hand, this is the result of highly competitive market and the survival of the fittest. In the first half of the past, B2C industry has competed on price. Because of the cost, the policy of free shipping has become a history. [1] B2C industries compete intensely, so the industry which only relies on the website's navigation system or search system will be more struggling because of the single profit model.

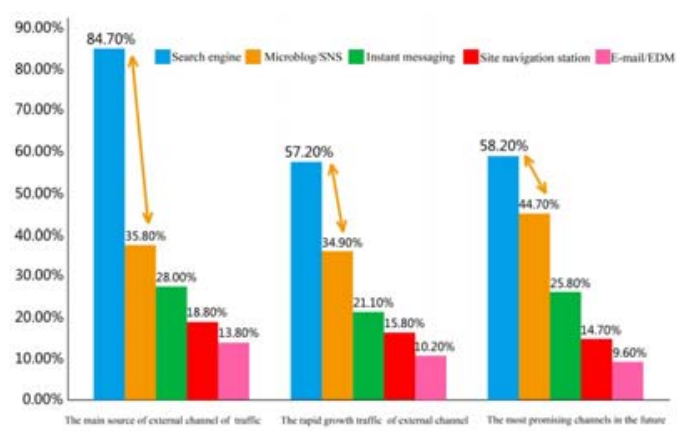

Figure 1. The traffic statistics of China's Internet website external source

The traffic statistics of China's Internet website external source which was released by China DCCI Internet Data Center shows that the function of search engine is further weakening. However, SNS-micro blogging has become a new power of website traffic growth, and social network connects to the future. [2]This further can explain enterprises that only rely on the website navigation system or search system can not succeed.

SNS social networking, micro blogging and the thirdparty e-commerce platform have brought a new development for e-commerce. According to the data from China Electronic Commerce Research Center, in 2011, the number of Internet users in China reached 520 million, and the number of its online shopping users reached to 189 million, which is a year-on-year growth of $19.6 \%$ than before. On the other hand, the number of Chinese social media users in 2011 reached to 460 million, which is a yearon-year growth of $30 \%$. China Electronic Commerce Research Center predicted that Chinese social media users are expected to reach to 570 million in 2012. [3]

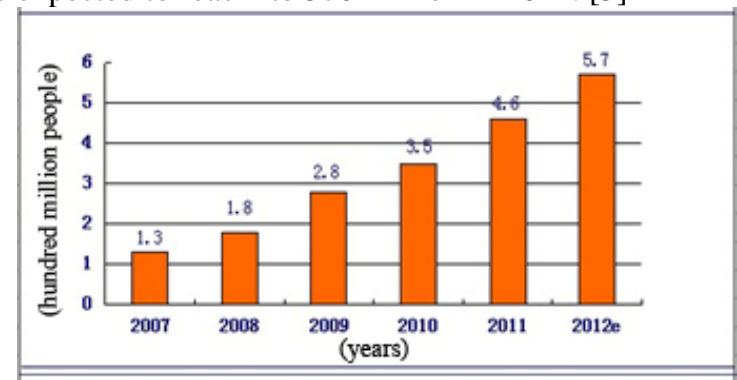

Figure 2. Chinese social media user scale from 2007 to 2012

The graph above shows that Chinese social media users are greatly increased year by year and the coverage rate of 
Social media in China is greatly improved. The same is with the social media, which is developing quite well in China.

Because of the rapid development of social media, more and more e-commerce enterprises have joined the rank of social media marketing. The protagonist of the social media platform is the user, and the content of social media is the combination of production and social. It leads to social media and e-commerce are more confluent in the development process. The strong development of social media and e-commerce made social e-commerce development become an inevitable trend, but also have brought new opportunities for more e-commerce enterprises. [4]

\section{THE SOCIALIZATION OF THE E-COMMERCE}

Social e-commerce is the e-commerce marketing method which is derived with the development of social media. It draws support from SNS social networking sites, micro blogging, online video, the third-party e-commerce service platform and social networking websites client side of Smartphone to communicate and marketing. Because of the number of social media users is increased greatly, the communication and interaction between users are also increased. Users can evaluate products and share experience after purchase. Thus, it can provide good publicity, marketing and service platform for e-commerce.

The Internet has increasingly become a mapping of the real life, and people's social attributes is shown through the Internet more and more. In addition, social e-commerce is hoped to spread through the people's social attributes by means of the Internet to spread, recommend commodities or service, and achieve the Internet-based consumption preferably. May 28, 2012, China e-commerce research center released "the investigation report of China's B2C ecommerce market in 2011.” The report shows that with the successful listing of Facebook, social commerce will get more and more capital concern. Social network as a medium has shown its characteristics, and has become the main channel of traffic.[5]

Information Filtering is used by social e-commerce, so it focused the information and avoids cockamamie research, and reduces the cost of consumer choice.

\section{EXISTING PROBlems OF SOCIAL E-COMMERCE MARKETING}

\section{A. For the enterprise}

- $\quad$ The network information is not be controlled

The development of social e-commerce make the information transfer more quickly. In fact, social media is more difficult to be controlled than traditional forms of media such as newspapers and TV. Product information and opinions will be spreaded through a social network, microblog or other websites in the moment. No matter consumers' online conversation is positive or negative, it will play an important influence on the company's brand.

- The increase of enterprise users makes the user be lack freshness
The development of social media reveals a promising prospect for many businesses in conjunction with the ecommerce. But not every business can shine on the social networking site. Social media platform is open to all enterprise users. Although more and more business users have registered on the social networking, users have been lacked the freshness.

\section{B. For users}

- Corporate advertising and false evaluation are increased

Large number of enterprises has joined in the social networking site SNS, microblog, blog and a third-party electronic business platform, which leads to the fierce competition between the enterprises that are on social media platform, and also leads to a lot of advertisings. For corporate reputation and business interests, enterprises put more and more corporate advertisings and product advertisings on the social network, and even some businesses use the false evaluation to get trust from the users, and then cheat interests.

- $\quad$ The lack of male platform

Mushroom Street and Beautiful Saying is the wellknown third-party e-commerce platform, but they are all women shopping sharing platform. As more and more men paying attention to their appearance, also they need more shopping sharing platform to facilitate their own purchase, but also to facilitate the girls help boys buy objects.

\section{The DeVELOPMENT Strategies of Social E- COMMERCE MARKETING}

\section{A. For enterprise}

- Pay attention to enterprises'brand construction

As network information is not controllable, either positive or negative information, it will play a major impact on the company. Even if it is a new type of marketing, corporate image still depend on the quality of the product as well as the user's praise to get success. So when do the social marketing in the company or e-commerce sites, enterprises should firstly focus on the quality of their products and brand building.

- $\quad$ Change the traditional marketing thinking model

As social e-commerce develops rapidly, the most important is that how to change the first mover advantage into the long-term competitiveness of enterprises, and maintain customers' entertainment and freshness. Business Professor Berger from Wharton School thinks that in order to take advantage of the SNS media marketing, you must change the marketing thinking model. "The former method of the business is to focus on consumer propaganda, but the new media is to encourage consumers to provide feedback on the product and brand." [6] At the same time, businesses can also estimate the content and product innovation which consumers participate in, and then they can make suggestions for the company's next development step.

For example: Red Bull is functional beverage which has established solid fans foundation. Facing the rapid 
development of Facebook, Red Bull set up their own home page on Facebook. In addition, Red Bull set up a powerful and interesting call to action on its website,and it makes users hard to escape the call when they go to the home page at the first time. However, only after you pay attention to the home page of Red Bull, you can see more information and application, and let users choose the application which is fit them.

What' s more, Red Bull also use active tabs to sort daily activities, and find ways to meet with fans. Also, Red Bull creatively coalesces it's brand logo into the tag box.

- Increasing the interactivity between enterprises and users

More and more enterprise users are registered for the social networks, and it makes users has been lack of freshness. Enterprises should conform to social trends and development, and enterprises need to take advantage of new activities to contact with users and new ways to closer the distance with users. Moreover, enterprises should improve the quality of pre-sales, sales and after-sale service, so they can retain more new and old customers.

Levi's which was initiated in 1853 is the worldrenowned brand of jeans, and it has ultra-high popularity and customer base In the world. Levi's jeans company has learned that the best platform to attract fans is the social networking site. In 2010, Levi's recruited a 23-year-old graduates named Garis who wes graduated from the University of Southern California on Twitter. Levi's let him use a pseudonym "Levi's boy" to attract consumers on Twitter. His duty is to reply and participate in a dialogue about the Levi's brand on Twitter. Meanwhile, Levi's also tried to recruit a "Levi's Girl". Mr. Megan who was Levi's digital marketing director said, they call Levi's boy and Levi's girl as brand ambassadors. Also, they let these brand ambassadors attract users and interact with customers on Twitter, and these brand ambassadors rapidly increased fan base on the network. [8]

\section{B. For users}

It is better for consumers to purchase items from the enterprise which you have a good impression on and you have ever bought products from. If you want to consume from enterprises where you have never purchased, it is better to consider others' opinions. Do not blindly trust the advertising or strangers, and it will reduce their own losses.

\section{For social media}

- Increasing network supervision dynamics

Users are deceived by large number of ads and can not understand the authenticity of information. Thus, Web platform can be managed further by the real identity system, and enterprises have to officially register to be users and ensure the information is reliable.

- Develop new platform and add new functions

It is very important to conform to the development of user's needs and develop more shopping platforms to meet the needs of different gender and ages users. At the same time, enterprises should increase platforms to search for classified projects, and update products as quickly as possible to meet the needs of customers.

\section{CONCLUSION}

As an important marketing model of e-commerce, although social e-commerce marketing model is still in the development stage, social e-commerce implies unlimited business opportunities. People believe that after continuous Improved, social e-commerce will provide more development opportunities for Chinese enterprises.

\section{REFERENCES}

[1] China electronic commerce research center, 2012, China e-commerce market data test report[EB/OL], http://www.100ec.cn/detail--6053686.html

[2] DCCI DATA CENTER OF CHINA INTERNET, 2011, China Internet market data report[EB/OL],

http://www.dcci.com.cn/media/download/7652de7adb385a1cb13574 8933d88326fc75.pdf

[3] China electronic commerce research center, the global social media marketing industry research report, $[\mathrm{EB} / \mathrm{OL}]$, http://www.100ec.cn/zt/mtyx/

[4] Lan Peng, "Why does electronic business need to be socializing”[J], Science \& Technology for China's Mass Media, Beijing, March.2012, pp16

[5] China electronic commerce research center, 2011 China B2C ecommerce market research report, [EB/OL], http://www.100ec.cn/detail--6040003.html

[6] Lin Li, “IT TIME” [J], Beijing, 16th period, 2010

[7] China Mobile, Facebook, examples of marketing success [EB/OL], http://labs.chinamobile.com/groups/10934_284417

[8] Brands are also crazy, "JingJiang evening news" [J/OL], Jiangsu, 2010 